\title{
Analysis of transpacific transport of black carbon during HIPPO-3: implications for black carbon aging
}

\author{
Z. Shen ${ }^{1, *}$, J. Liu ${ }^{1}$, L. W. Horowitz ${ }^{2}$, D. K. Henze ${ }^{3}$, S. Fan ${ }^{2}$, Levy II H. ${ }^{2}$, D. L. Mauzerall ${ }^{4,5}$, J.-T. Lin ${ }^{6}$, and S. Tao ${ }^{1}$ \\ ${ }^{1}$ College of Urban and Environmental Sciences, Peking University, Beijing, China \\ ${ }^{2}$ NOAA Geophysical Fluid Dynamics Laboratory, Princeton, NJ, USA \\ ${ }^{3}$ Department of Mechanical Engineering, University of Colorado, Boulder, CO, USA \\ ${ }^{4}$ Woodrow Wilson School of Public and International Affairs, Princeton University, Princeton, NJ, USA \\ ${ }^{5}$ Department of Civil and Environmental Engineering, Princeton University, Princeton, NJ, USA \\ ${ }^{6}$ Laboratory for Climate and Ocean-Atmosphere Studies, Department of Atmospheric and Oceanic Sciences, School of \\ Physics, Peking University, Beijing 100871, China \\ *now at: Program in Atmospheric and Oceanic Sciences, Princeton University, Princeton, NJ, USA
}

Correspondence to: J. Liu (jfliu@pku.edu.cn)

Received: 18 November 2013 - Published in Atmos. Chem. Phys. Discuss.: 9 January 2014

Revised: 26 April 2014 - Accepted: 13 May 2014 - Published: 25 June 2014

\begin{abstract}
Long-range transport of black carbon (BC) is a growing concern as a result of the efficiency of $\mathrm{BC}$ in warming the climate and its adverse impact on human health. We study transpacific transport of BC during HIPPO-3 using a combination of inverse modeling and sensitivity analysis. We use the GEOS-Chem chemical transport model and its adjoint to constrain Asian $\mathrm{BC}$ emissions and estimate the source of BC over the North Pacific. We find that different sources of $\mathrm{BC}$ dominate the transport to the North Pacific during the southbound (29 March 2010) and northbound (13 April 2010) measurements in HIPPO-3. While biomass burning in Southeast Asia (SE) contributes about $60 \%$ of BC in March, more than $90 \%$ of $\mathrm{BC}$ comes from fossil fuel and biofuel combustion in East Asia (EA) during the April mission. GEOS-Chem simulations generally resolve the spatial and temporal variation of $\mathrm{BC}$ concentrations over the North Pacific, but are unable to reproduce the low and high tails of the observed $\mathrm{BC}$ distribution. We find that the optimized $\mathrm{BC}$ emissions derived from inverse modeling fail to improve model simulations significantly. This failure indicates that uncertainties in BC removal as well as transport, rather than in emissions, account for the major biases in GEOS-Chem simulations of BC over the North Pacific.

The aging process, transforming $\mathrm{BC}$ from hydrophobic into hydrophilic form, is one of the key factors controlling wet scavenging and remote concentrations of BC. Sensitiv-
\end{abstract}

ity tests on $\mathrm{BC}$ aging (ignoring uncertainties of other factors controlling BC long range transport) suggest that in order to fit HIPPO-3 observations, the aging timescale of anthropogenic BC from EA may be several hours (faster than assumed in most global models), while the aging process of biomass burning BC from SE may occur much slower, with a timescale of a few days. To evaluate the effects of $\mathrm{BC}$ aging and wet deposition on transpacific transport of $\mathrm{BC}$, we develop an idealized model of $\mathrm{BC}$ transport. We find that the mid-latitude air masses sampled during HIPPO-3 may have experienced a series of precipitation events, particularly near the EA and SE source region. Transpacific transport of $\mathrm{BC}$ is sensitive to $\mathrm{BC}$ aging when the aging rate is fast; this sensitivity peaks when the aging timescale is in the range of $1-1.5 \mathrm{~d}$. Our findings indicate that $\mathrm{BC}$ aging close to the source must be simulated accurately at a process level in order to simulate better the global abundance and climate forcing of BC.

\section{Introduction}

Black carbon (BC) strongly absorbs solar and infrared radiation, resulting in a positive radiative forcing of climate (Ramanathan and Carmichael, 2008). When internally mixed with other aerosols, BC acts as cloud condensation nuclei $(\mathrm{CCN})$ and thus plays an important role in modifying 
cloud formation and precipitation (Zuberi et al., 2005). After deposition to snow/ice surfaces, $\mathrm{BC}$ causes additional climate warming by reducing surface albedo and accelerating snow/ice melting (Fiore et al., 2012). Through these various pathways, BC is estimated to have contributed significantly to global warming and to have affected both global and regional climate (Ramanathan and Carmichael, 2008). Recently, the climate forcing of $\mathrm{BC}$ has been estimated to be $+1.1 \mathrm{~W} \mathrm{~m}^{-2}$, making BC the second most important anthropogenic climate forcer after carbon dioxide $\left(\mathrm{CO}_{2}\right)$ (Bond et al., 2013). Besides its warming effects, $\mathrm{BC}$ is also a potent pollutant that adversely impacts air quality, visibility, and human health (Highwood and Kinnersley, 2006).

Intercontinental transport of $\mathrm{BC}$ is increasingly of concern as a result of its great effect on climate change and air quality. However, large uncertainties remain in modeling global transport of $\mathrm{BC}$ and previous studies show large spatialtemporal differences between simulated and observed $\mathrm{BC}$ concentrations. Despite large inter-model differences in simulated $\mathrm{BC}$ concentrations, models generally overestimate BC in the mid-upper troposphere in the tropics and mid-latitudes, but underestimate $\mathrm{BC}$ in the lower and middle troposphere at high latitudes compared to aircraft measurements (Fan et al., 2012; Koch et al., 2009; Schwarz et al., 2010, 2013). Model biases result from many factors of the simulations, including $\mathrm{BC}$ emissions and the parameterizations of $\mathrm{BC}$ aging, wet removal, and dry deposition processes (Liu et al., 2011).

Uncertainty in emission inventories has been shown to contribute significantly to the biases in $\mathrm{BC}$ modeling (Hakami et al., 2005). BC is emitted from incomplete combustion of fossil fuels and biofuels. Many factors contribute to this uncertainty in bottom-up inventories, such as BC emission factors, activity data, burned area, and combustion completeness (Bond et al., 2013). Global and regional emission inventories of BC vary over a wide range and have been refined several times (Bond et al., 2004, 2007; Lamarque et al., 2010; Textor et al., 2007; see also discussion in Bond et al., 2013).

Physical and chemical processes occurring during longrange transport of $\mathrm{BC}$ also play important roles in simulated concentrations of BC. Parameterizations of $\mathrm{BC}$ aging, dry deposition, and wet deposition significantly affect model results (Liu et al., 2011). Freshly emitted BC aerosols are predominantly hydrophobic and may become hydrophilic when soluble compounds, such as ammonium sulfate, attached to the surface (Cooke et al., 2002). The aging process refers to a transformation from hydrophobic to hydrophilic aerosols, with the latter treated as $\mathrm{CCN}$ in the aerosol wet deposition processes. Therefore, the rate of $\mathrm{BC}$ aging significantly affects the atmospheric lifetime of $\mathrm{BC}$, is one of the key factors controlling long-range transport of $\mathrm{BC}$, and affects the global BC burden and distribution (Croft et al., 2005; Riemer et al., 2004). However, the aging of BC is highly simplified in global models, which typically assume either a fixed or a pa- rameterized aging rate (Cooke et al., 2002; Koch, 2001; Koch and Hansen, 2005; Liu et al., 2011; Riemer et al., 2004).

Aged BC particles can act as CCN and be removed by incloud scavenging when $\mathrm{BC}$ is trapped in cloud droplets or ice crystals (Liu et al., 2011). The Bergeron process (i.e., evaporation of liquid droplets in the presence of ice crystals in mixed-phase clouds) releases $\mathrm{BC}$-containing $\mathrm{CCN}$ back into the interstitial phase (Cozic et al., 2007) and decreases the efficiency of wet removal in mixed-phase clouds. Dry deposition also accounts for a large portion of total removal of $\mathrm{BC}$, but its relative importance varies across models (Koch et al., 2009; Shindell et al., 2008). There are large differences in the dry deposition velocities used in models, resulting from different assumptions and methods of parameterization (Liu et al., 2011).

Transpacific transport of air pollution is of great significance to air quality at locations remote from the pollutant sources and is a major concern for both scientists and policy makers (Fiore et al., 2002; Jaegle et al., 1998; Liu et al., 2005, 2009a; Lin et al., 2014; Lu et al., 2011). The lack of BC measurements (particularly over remote areas) for model evaluation makes it difficult to represent accurately the longrange transport and global distribution of BC aerosols. Recently, the HIAPER pole-to-pole observations (HIPPO) campaign (Wofsy et al., 2011) sampled the atmosphere from the North Pole to the coastal waters of Antarctica, covering much of the remote Pacific. HIPPO provides global-scale, highresolution, and previously unobtainable data for the distributions of many atmospheric constituents including BC, which can help calibrate global emissions and evaluate the transport processes of BC, particularly over the Pacific. As HIPPO sampled a large number of $\mathrm{BC}$ plumes over the North Pacific, analyzing sources that contribute to the presence of $\mathrm{BC}$ in these plumes is critical to explore the mechanisms of pollution transport to the North Pacific region.

Inverse modeling provides a powerful approach for optimization of atmospheric model inputs, especially emissions, based on observations of atmospheric composition and knowledge of atmospheric processes (Hakami et al., 2005). Previous studies solved the inverse problem using methods suitable for adjusting a few emissions scaling factors over broad regions (Fu et al., 2012; Park et al., 2003; Wang et al., 2013). The adjoint method developed in recent studies overcomes this difficulty by enabling grid-scale refinement of emissions factors (Hakami et al., 2005). An adjoint model itself is also an efficient way to calculate source-receptor sensitivities (Henze et al., 2007). Many studies have applied the adjoint method to analyze the origin of atmospheric pollution at a particular site (Kharol et al., 2013; Kopacz et al., 2011; Zhang et al., 2009) and to improve the global emission inventories of atmospheric pollutants (Hakami et al., 2005; Henze et al., 2009; Muller and Stavrakou, 2005). Since the model is considered as a strong constraint in the adjoint analysis (Hakami et al., 2005), uncertainties in physical and chemical processes during long-range transport of $\mathrm{BC}$ may 
considerably affect the results. This paves the way to use inverse modeling to study the influence of factors other than $\mathrm{BC}$ emissions (e.g., BC aging, wet removal, and dry deposition) on $\mathrm{BC}$ simulation in models.

Here we use the adjoint of GEOS-Chem (Henze et al., 2007) to study $\mathrm{BC}$ emissions and transport during the HIPPO-3 campaign. We study the source of BC emissions using both sensitivity analysis and inverse modeling. As the aging process is a key factor governing remote-BC concentrations (Liu et al., 2011), we conduct a number of sensitivity tests on BC aging and develop an idealized BC transport model to investigate the key factors affecting transpacific transport. These simulations reinforce the importance of a process-level simulation on $\mathrm{BC}$ aging and make recommendations for improving simulations of $\mathrm{BC}$ in global models.

We describe our method in Sect. 2. In Sect. 3, we analyze the origin of BC over the North Pacific during the HIPPO3 campaign. In Sect. 4, we evaluate the simulated BC distribution against the HIPPO-3 and constrain BC emissions through inverse modeling. In Sect. 5, we assess the impact of aging rate on transpacific transport of BC. Finally, we draw conclusions in Sect. 6.

\section{Method}

\subsection{The HIPPO aircraft campaign}

The HIPPO campaign consisted of five global aircraft measurement deployments completed in January and November 2009, March-April 2010, June and August-September 2011, spanning the Pacific from $85^{\circ} \mathrm{N}$ to $70^{\circ} \mathrm{S}$, with vertical profiles every $2.2^{\circ}$ latitude from the surface to $14 \mathrm{~km}$ (Wofsy et al., 2011). BC particles were measured by the NOAA singleparticle soot photometer (SP2). The SP2 measures the refractory $\mathrm{BC}$ mass in particles by analyzing the thermal radiation emitted by a particle when being heated (Schwarz et al., 2008). We use the HIPPO-3 data (including two flights spanning the North Pacific on 29 March and 13 April 2010) (Wofsy et al., 2012; http://hippo.ornl.gov/) and focus on a region over the central North Pacific $\left(30-50^{\circ} \mathrm{N}, 150-160^{\circ} \mathrm{W}\right.$; 2-6 km) where large concentrations of $\mathrm{BC}$ are observed in order to study the outflow of BC aerosols from East Asia (EA) and Southeast Asia (SE). We use these observational data to evaluate the model and constrain $\mathrm{BC}$ emissions, mainly because the mid-latitude transport of Asian plumes is fastest in spring (Liu et al., 2005), and we focus on the region between $2 \mathrm{~km}$ and $6 \mathrm{~km}$ to weaken the influence of $\mathrm{BC}$ emissions from ocean surfaces, $\mathrm{BC}$ dry deposition, and uncertainty of $\mathrm{BC}$ transport and removal in the upper troposphere, as we mainly study the effect of $\mathrm{BC}$ aging in the following analysis.

\subsection{GEOS-Chem model and its adjoint}

GEOS-Chem (www.geos-chem.org) is a global 3-D chemical transport model (CTM) of atmospheric composition driven by assimilated meteorological observations from the Goddard Earth Observing System (GEOS-5) of the NASA Global Modeling Assimilation Office (GMAO) (Bey et al., 2001). Here we use the GEOS-Chem model (version 9-0103 ) with a horizontal resolution of $2^{\circ}$ latitude by $2.5^{\circ}$ longitude and 47 vertical layers to simulate $\mathrm{BC}$ concentrations for March and April 2010, following six months of spin-up. $\mathrm{BC}$ simulations in GEOS-Chem have been evaluated over the United States using surface measurements from the Interagency Monitoring of Protected Visual Environments (IMPROVE) network (Park et al., 2003) and over the Himalayas and the Tibetan Plateau using wet deposition flux measurements (Kopacz et al., 2011). The simulation of BC in GEOSChem has been discussed by Park et al. (2003) and Park et al. (2005); here we describe the key features of the BC simulation, as they pertain to this study.

We use the Bond et al. (2007) global BC emission inventory with global annual emissions totaling about $4.4 \mathrm{Tg}$ from fossil fuel and biofuel combustion. We use the biomass burning emissions from the GFED3 inventory in 2010 (van der Werf et al., 2010). The model treats hydrophobic and hydrophilic BC as two separate transported species (Park et al., 2005). In all, $80 \%$ of BC emitted from all primary sources is hydrophobic, and is transformed into hydrophilic form with a prescribed e-folding time of 1.15 days (Cooke et al., 2002). Wet deposition, including contributions from scavenging in convective updrafts, rainout from convective anvils, and rainout and washout from large-scale precipitation, is applied only to hydrophilic BC. Dry deposition is implemented following a standard resistance-in-series scheme as described by Wang et al. (1998). Dry deposition is not important for fine aerosols (Park et al., 2005) and is small compared to wet deposition in BC simulation (Park et al., 2003). In GEOSChem, the global annual mean dry deposition velocity for $\mathrm{BC}$ is $0.1 \mathrm{~cm} \mathrm{~s}^{-1}$, which is typical of current models (Wang et al., 2011).

The GEOS-Chem adjoint model derives from the GEOSChem forward model and is discussed in detail by Henze et al. (2007). The adjoint model provides an efficient calculation of model sensitivities and is a powerful tool for inverse problems (Henze et al., 2007). The model has been applied to evaluate sources of aerosols, $\mathrm{CO}$, and ozone (Henze et al., 2009; Zhang et al., 2009; Kopacz et al., 2009). For example, Kopacz et al. (2011) used the adjoint model to analyze the origin of $\mathrm{BC}$ concentrations over the Himalayas and Tibetan Plateau.

Here we apply the GEOS-Chem adjoint model (version 34 with updates to v8-02-01) at a resolution of $2^{\circ} \times 2.5^{\circ}$ to analyze the origin of $\mathrm{BC}$ transported to the North Pacific during HIPPO-3. Since the BC source-receptor relationship is nearly linear in the model, contributions of $\mathrm{BC}$ emissions to 
BC concentrations at specific locations can be estimated by multiplying the adjoint sensitivities by emissions (Kopacz et al., 2011). We conduct two separate one-month simulations for 1 March-1 April and 15 March-15 April 2010 to simulate the evolution of BC concentrations over the North Pacific approaching the southbound (29 March) and northbound (13 April) measurements in HIPPO-3, respectively, and compute the emission contributions to $\mathrm{BC}$ concentrations in the observation domain at the time of the two HIPPO3 flights. We also use the adjoint model to constrain Asian BC emissions with the HIPPO-3 data, as described below.

\subsection{Inverse modeling}

Considering a general chemical transport model (CTM), for which the forward model can be written as $\mathbf{y}=\mathbf{F}(\mathbf{x})+\boldsymbol{\varepsilon}$, where $\mathbf{x}$ is emissions, $\mathbf{y}$ is observed concentrations, $\mathbf{F}$ represents the model, and $\varepsilon$ is the error term. Through inverse modeling, we can obtain the best estimate of $\mathbf{x}$ given observations corresponding to the model estimates. Bayesian inverse modeling solves the problem of obtaining the maximum a posteriori (MAP) solution for $\mathbf{x}$ based on Bayes' theorem and assumption of Gaussian errors by minimizing the cost function $J(\mathbf{x})$ (Rodgers, 2000):

$J(\mathbf{x})=(\mathbf{F}(\mathbf{x})-\mathbf{y})^{\mathrm{T}} \mathbf{S}_{\varepsilon}^{-1}(\mathbf{F}(\mathbf{x})-\mathbf{y})+\left(\mathbf{x}-\mathbf{x}_{\mathrm{a}}\right)^{\mathrm{T}} \mathbf{S}_{\mathrm{a}}^{-1}\left(\mathbf{x}-\mathbf{x}_{\mathrm{a}}\right)$,

where $\mathbf{x}_{\mathrm{a}}$ is a priori estimate of $\mathbf{x}$ with error $\boldsymbol{\varepsilon}_{\mathrm{a}}, \mathbf{S}_{\varepsilon}$ and $\mathbf{S}_{\mathrm{a}}$ are the observational and a priori error covariance matrices.

The cost function is minimized using gradient:

$\nabla_{\mathbf{x}} J(\mathbf{x})=2 \mathbf{S}_{\mathrm{a}}^{-1}\left(\mathbf{x}-\mathbf{x}_{\mathrm{a}}\right)+2 \nabla_{\mathbf{x}} \mathbf{F}^{\mathrm{T}} \mathbf{S}_{\varepsilon}^{-1}(\mathbf{F}(\mathbf{x})-\mathbf{y})=0$.

The adjoint approach provides an efficient means of calculating this gradient when the dimension of $\mathbf{x}$ is large. To apply the adjoint method to calculate $\nabla_{\mathbf{x}} J(\mathbf{x})$ over a time period $\left[t_{0}, t_{n}\right]$, we compute adjoint forcing $\mathbf{S}_{\varepsilon}^{-1}(\mathbf{F}(\mathbf{x})-\mathbf{y})$ at time $t_{n}$ and run backward until $t_{0}$, applying additional adjoint forcing throughout the adjoint integration (Henze et al., 2009; Kopacz et al., 2009). Starting from the initial guess of $\mathbf{x}_{\mathrm{a}}$, the minimum of $J(\mathbf{x})$ is then sought through an iterative gradient-based quasi Newton optimization algorithm (Byrd et al., 1995; Zhu et al., 1994).

The determination of the error covariance matrices $\mathbf{S}_{\mathrm{a}}$ and $\mathbf{S}_{\varepsilon}$ is key to the inverse problem. In this study, the error in fossil fuel and biofuel emissions is estimated to be $100 \%$ and the error of biomass burning is estimated to be $200 \%$ (Bond et al., 2004, 2007). $\mathbf{S}_{\mathrm{a}}$ is assumed to be diagonal, which means error correlation between different locations and different sources of emissions is neglected. $\mathbf{S}_{\varepsilon}$ is a sum of the covariance matrices of the instrument error, the representation error, and the forward model error (Heald et al., 2004). The representation error is taken to be $30 \%$ of the observation if the model overestimated $\mathrm{BC}$ concentrations and $30 \%$ of the model results if the model underestimated BC concentrations (Henze et al., 2009). As the resolution of our simulation is coarse and the SP2 measurement has relatively high accuracy (Gao et al., 2007; Laborde et al., 2012), the instrument error and the forward model error could be small compared to the representation error and are neglected in our study following the work of Henze et al. (2009). $\mathbf{S}_{\varepsilon}$ is also assumed to be diagonal.

\subsection{Idealized transpacific BC transport model}

We develop an idealized model to study the key factors governing transpacific transport of BC. We assume that a fixed ratio $\alpha$ of freshly emitted $\mathrm{BC}$ is hydrophobic and parameterize the aging process using a fixed e-folding time. In addition, we assume BC is removed solely by several independent precipitation events and the effect of dry deposition is ignored. Thus, the whole transport process can be simplified as

$$
\begin{aligned}
& C=\alpha E e^{-\frac{T_{N}}{\tau}}+\sum_{n=1}^{N-1} \alpha E e^{-\frac{T_{n}}{\tau}}\left(1-e^{-\frac{T_{n+1}-T_{n}}{\tau}}\right) \\
& \left(1-R_{n+1}\right) \cdots\left(1-R_{N}\right) \\
& +\left[(1-\alpha) E+\alpha E\left(1-e^{-\frac{T_{1}}{\tau}}\right)\right]\left(1-R_{1}\right) \cdots\left(1-R_{N}\right),
\end{aligned}
$$

where $C$ is the amount of BC transported to a certain domain, $E$ is BC emission, $N$ is the number of precipitation events, $T_{n}$ is the time interval between $\mathrm{BC}$ emissions and the $n$th precipitation, $\tau$ is the e-folding time of $\mathrm{BC}$ aging, and $R_{n}$ is the fraction of $\mathrm{BC}$ removed by the $n$th precipitation.

In this study we assume that the BC sampled by HIPPO-3 may experience a number $(N)$ of distinct precipitation events after it is released from EA and SE, while in reality it is more likely that there is continuous precipitation during midlatitude transpacific transport. We also put all $\mathrm{BC}$ emissions from different source regions at different times into one single variable $(E)$, while the time for transpacific transport of $\mathrm{BC}$ emitted at different times and locations is different. As a result, all the variables derived from the equation are averages of our simulation periods, and the goal of our idealized model is to analyze the general precipitation and wet removal patterns which determine transpacific transport of $\mathrm{BC}$ during HIPPO-3.

Many models treat BC aging as an exponential decay process with a fixed e-folding time in the range of 1-2 d (Chung and Seinfeld, 2002; Cooke et al., 2002; Liu et al., 2009b; Park et al., 2003). However, large uncertainties remain and a number of studies have indicated a faster aging rate (Croft et al., 2005; Riemer et al., 2004, 2010). In this study, we conduct sensitivity runs on $\mathrm{BC}$ aging with a series of e-folding times $(0.5 \mathrm{~h}, 1 \mathrm{~h}, 2 \mathrm{~h}, 4 \mathrm{~h}, 6 \mathrm{~h}, 8 \mathrm{~h}, 10 \mathrm{~h}, 20 \mathrm{~h}, 1.15 \mathrm{~d}, 1.67 \mathrm{~d}$, $2.5 \mathrm{~d}, 5 \mathrm{~d}, 10 \mathrm{~d}, 20 \mathrm{dd}, 30 \mathrm{~d}$, and $60 \mathrm{~d}$ ) to analyze the impact of BC aging on GEOS-Chem model simulations of BC over the North Pacific and transpacific transport of BC during HIPPO-3. We then fit the parameters in Eq. (3) to best match the results of these simulations, in order to estimate 


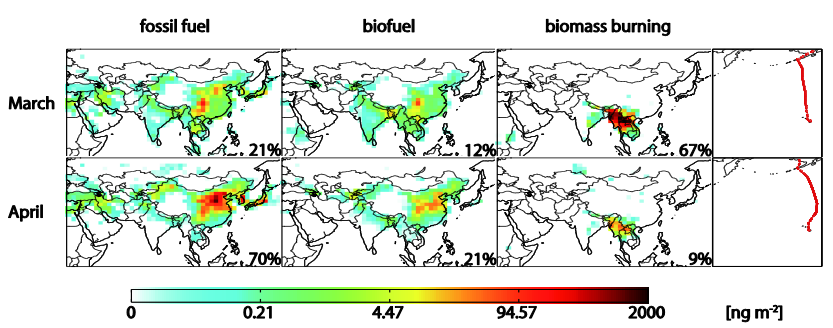

Figure 1. Adjoint model sensitivities of $\mathrm{BC}$ concentrations in the HIPPO-3 observational domain over the North Pacific $\left(30-50^{\circ} \mathrm{N}\right.$, $150-160^{\circ} \mathrm{W} ; 2-6 \mathrm{~km}$ ) in March and April missions with respect to BC emissions from fossil fuel combustion (left), biofuel combustion (middle), and biomass burning (right). The percentages listed on each plot indicate the relative total contribution of specific $\mathrm{BC}$ sources in each month. The HIPPO-3 flight tracks are also shown. The observations used in this study are shown with solid lines. The rest observations during the flights are shown with dashed lines.

the general features of precipitation events that remove BC along the transpacific transport during HIPPO-3.

\section{Origin of BC over the North Pacific}

Previous studies have shown that due to rapid industrialization, Asian anthropogenic emissions may influence air quality and climate over the North Pacific and downwind regions (Holzer et al., 2005; Lin et al., 2008; M. Y. Lin et al., 2012; Wuebbles et al., 2007; Zhang et al., 2007). To understand the degree to which BC measured in HIPPO-3 originates from Asia, we conduct an adjoint sensitivity simulation. Figure 1 shows the source attribution of $\mathrm{BC}$ over the central North Pacific (2-6 km above the surface) in March and April. Specifically, the maps show the amount of $\mathrm{BC}$ arriving at the HIPPO-3 observation domain (mentioned in Sect. 2.1) from each grid box in the Asian source domain $\left(0-60^{\circ} \mathrm{N}\right.$, $\left.30-150^{\circ} \mathrm{E}\right)$.

As shown in Fig. 1, more than $90 \%$ of $\mathrm{BC}$ arriving at the observational domain originates from Asia and the Middle East in both the March and April missions of HIPPO-3. However, the contributions from various $\mathrm{BC}$ sources between the two missions are quite different. During the southbound measurements on 29 March the adjoint sensitivity shows that biomass burning emissions in Indo-China Peninsula, especially in southern China, Burma, and northern Thailand have a major contribution (67\%) to BC over the central North Pacific, largely because biomass burning in SE peaks in March (Duncan et al., 2003). In this study, BC emissions from biomass burning in SE based on GFED3 inventory in March are larger than those in April by a factor of 6. Fossil fuel and biofuel combustion in China and India is also an important source of $\mathrm{BC}$ transported across the Pacific. In terms of the northbound measurements on 13 April fossil fuel combustion in Asia and the Middle East, China, in particular, is the most important source of BC that reached the North Pacific

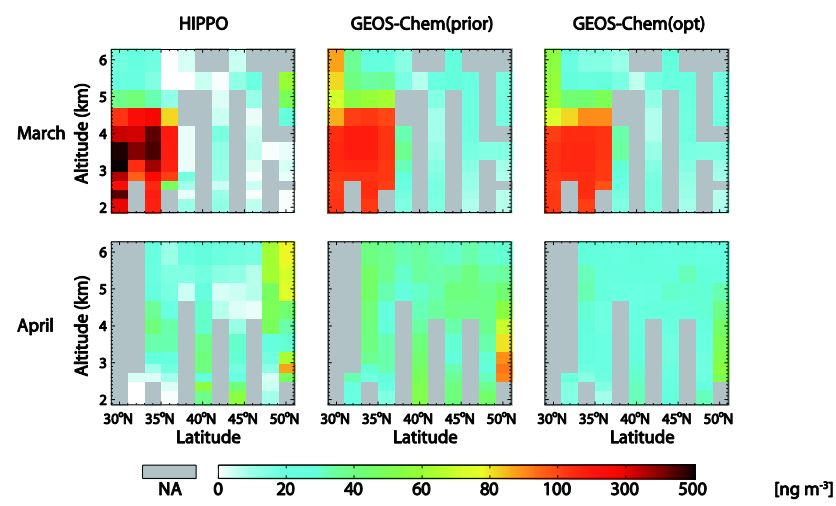

Figure 2. BC vertical profiles in the observational domain (150$160^{\circ} \mathrm{W}$ ) on 29 March 2010 (top) and 13 April 2010 (bottom). HIPPO aircraft observations (left) and GEOS-Chem model estimates (sampled along aircraft track) using the prior (center) and the optimized (right) $\mathrm{BC}$ emissions are shown.

(70\%) since transport of Asian tracers across the Pacific becomes fastest (Liu et al., 2005). In contrast, the contribution of biomass burning in SE to BC over the central North Pacific is much smaller $(9 \%)$.

\section{Uncertainties in BC simulations: emission vs. transport?}

Model evaluation against observations in regions remote from sources is important for assessing long-range transport of air pollutants. Previous studies have evaluated the model performance on BC with the NASA ARCTAS aircraft measurements (Wang et al., 2011) as well as the observed wet deposition data in the Himalayas and the Tibetan Plateau (Kopacz et al., 2011). Here, we evaluate the simulated BC with the HIPPO-3 data. In Fig. 2, the left and middle columns show the comparison between the observed and model simulated BC concentrations over the central North Pacific during HIPPO-3. Observations are averaged according to the model grids and model results are averaged over a $6 \mathrm{~h}$ period containing the HIPPO measurements. As shown in Fig. 2, large latitudinal and vertical gradients in $\mathrm{BC}$ concentrations appear during HIPPO-3, especially in March (ranging from $\sim 500 \mathrm{ng} \mathrm{m}^{-3}$ over the lower subtropics to $\sim 10 \mathrm{ng} \mathrm{m}^{-3}$ over the higher latitude and altitude regions). When comparing the two flights in March and April, there is also an apparent change in the spatial pattern of the BC measurements. Much less $\mathrm{BC}$ is present during the April flights, particularly over the subtropical regions.

The model generally captures the spatial pattern of BC concentrations over the central North Pacific in March, but is unable to reproduce the low end and the high end of $\mathrm{BC}$ observations. In particular, the large-observed pollution plumes $\left(\mathrm{BC}>200 \mathrm{ng} \mathrm{m}^{-3}\right)$ are not well captured by the model. Model simulated BC concentrations are highest at 


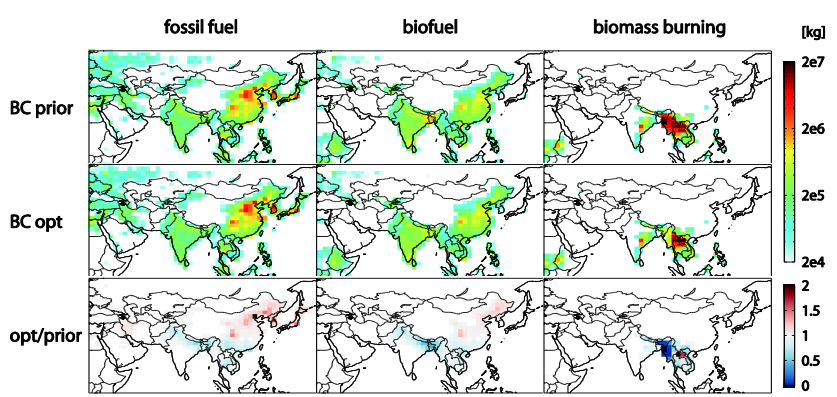

Figure 3. BC emissions from different sources during 1 March-1 April 2010. The top row shows the prior inventory, the middle row shows the posterior inventory, and the bottom row shows the scaling factors.

$30-35^{\circ} \mathrm{N}$, which is similar to observations. However, observations indicate much larger $\mathrm{BC}$ concentrations than simulated at lower altitudes and smaller BC concentrations at higher altitudes near $30^{\circ} \mathrm{N}$. The excessive vertical extent of $\mathrm{BC}$ in the model may result from the difficulty of resolving sharp chemical gradients in intercontinental pollution plumes in Eulerian CTMs, due to numerical plume dissipation (Rastigejev et al., 2010). The model generally overpredicts BC concentrations at high altitudes in both March and April, which may be owing to insufficient model wet removal in the upper troposphere over the tropical Pacific (Fan et al., 2012).

There is larger disagreement between model simulations and observations in April, as the model cannot resolve the spatial variation of observed $\mathrm{BC}$ concentrations. The model generally overestimates $\mathrm{BC}$ at $40-45^{\circ} \mathrm{N}$. Another major bias is that there is an overestimate in model simulations at lower altitudes and an underestimate at higher altitudes near $50^{\circ} \mathrm{N}$, mainly because there are large uncertainties in the calculations of vertical transport of BC (Koffi et al., 2012; Oshima et al., 2013). Oshima et al. (2013) identified that the uplifting of $\mathrm{BC}$ in association with migratory cyclones over northeastern China and the subsequent BC transport by the midlatitude westerlies provided the major pathway for $\mathrm{BC}$ export from EA to the free troposphere over the western Pacific during the springtime A-FORCE period. Here the observed high BC concentrations aloft in April may be caused by the same mechanism. Similar model biases are found when we compare GEOS-Chem model simulated CO concentrations over the North Pacific with observations in April measurements during HIPPO-3 (not shown), which further indicates that large uncertainties remains in modeling the vertical transport processes.

To identify the factors causing the model biases, we first constrain BC emissions with the HIPPO-3 data, assuming that errors in $\mathrm{BC}$ emissions contribute most to the simulation biases. Figures 3 and 4 show the prior and posterior (optimized) $\mathrm{BC}$ emissions and the ratio of posterior to prior $\mathrm{BC}$ emissions (scaling factors) during March and April 2010, re-

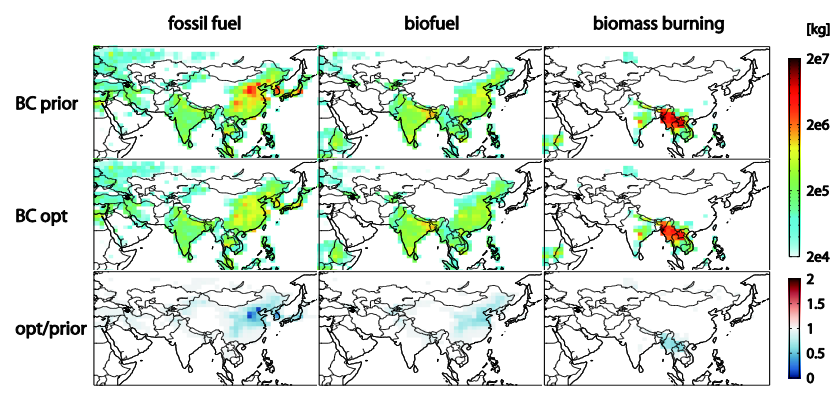

Figure 4. Same as Fig. 3, but for BC emissions from different sources during 15 March-15 April 2010.

spectively. While the prior and the optimized Asian BC emissions have similar spatial patterns in both March and April, there are large differences between the optimized emission scaling factors in the two months. In March, the optimized $\mathrm{BC}$ emissions from fossil fuel (and biofuel) combustion in South and East China as well as Korea and Japan yield a $\sim 15 \%$ increase relative to the a priori estimate. There is also a small decrease in anthropogenic BC emissions in the regions adjacent to the Himalayas and southern Tibetan Plateau, as well as a large decrease (increase) in BC emissions from biomass burning across Burma (North Laos). In April, the overall result is a reduction in $\mathrm{BC}$ emissions from all sources. The largest reduction occurs in anthropogenic $\mathrm{BC}$ emissions in North China, which decrease by $\sim 50 \%$. The decrease in $\mathrm{BC}$ emissions from biomass burning is relatively smaller.

In this study we do not attempt to provide an accurate topdown estimate of Asian BC emissions due to substantial uncertainties remaining in our inversion. First of all, the prior error covariance, $\mathbf{S}_{\mathrm{a}}$, and the observational error covariance, $\mathbf{S}_{\varepsilon}$ are not adequately characterized. $\mathbf{S}_{\mathrm{a}}$ and $\mathbf{S}_{\varepsilon}$ are treated as diagonal, and we use a uniform error for each $\mathrm{BC}$ source, whereas $\mathrm{BC}$ emissions in some regions may have greater uncertainties (Bond et al., 2004). We assume the representation error dominates the observational error and neglect the model error and the instrument error which also have some effect on the inversion. In fact, the forward model error may be important in the inverse modeling when model simulation is highly uncertain (J. T. Lin et al., 2012; Lin and McElroy, 2010; Wang et al., 2013). The resolution at which we are able to constrain the emissions is also dependent upon the observation domain and the study domain we choose. In addition, the model resolution significantly affects the optimized emissions (Wang et al., 2013).

As a result of these uncertainties, our target is instead to explore the extent to which the simulated BC biases are tied to the uncertainties in emissions. Although the parameters used in the inverse modeling may affect the result, perturbation tests on the parameters used in inverse modeling (e.g., assuming observational error to be $40 \%$ and increasing the prior error by a factor of 10) do not yield much different 

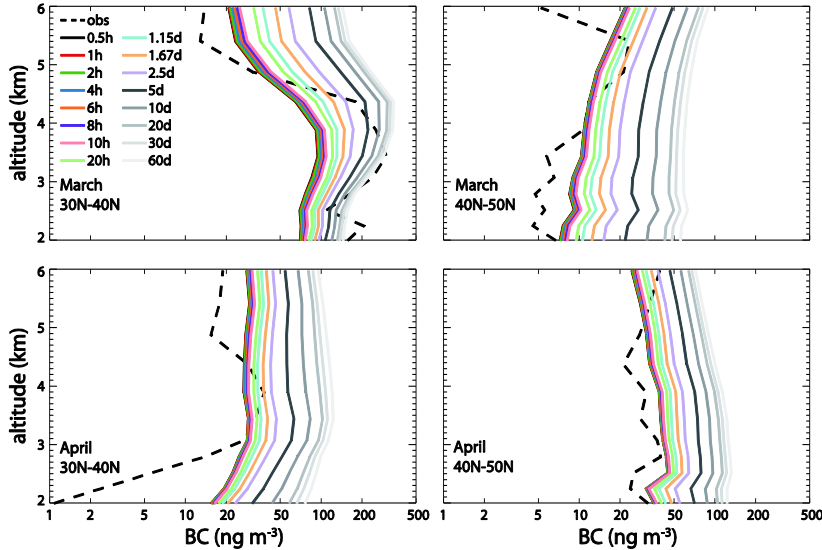

Figure 5. BC vertical profiles over the North Pacific on 29 March 2010 and 13 April 2010 from sensitivity simulations of GEOSChem with varying e-folding aging times $(\tau)$. HIPPO measurements are shown with dashed black lines. Colored lines indicate model predicted $\mathrm{BC}$ vertical profiles with indicated e-folding aging times.

optimized emissions. Since we constrain Asian BC emissions with HIPPO data over the North Pacific, BC transport plays an important role in the inversion and contributes to the uncertainty of our results.

Model simulated $\mathrm{BC}$ concentrations using the posterior emissions are shown in the right column in Fig. 2. The model biases relative to HIPPO data decrease to some extent, but no significant improvement in model simulations is found. The optimized BC emissions cannot alter the spatial distribution of model results, which is inconsistent with observations, especially in April. Despite having a variety of uncertainties, the inverse modeling result for BC based on HIPPO-3 aircraft observations has some implications. Since optimizing the $\mathrm{BC}$ emissions fails to reduce the simulation biases significantly, we conclude that uncertainties in BC transport pose an important role to limit the capability of inverse modeling in optimization of $\mathrm{BC}$ emissions.

\section{$5 \quad \mathrm{BC}$ aging and wet deposition during transpacific transport}

Wet deposition is the key process determining the efficiency of transpacific transport of BC (Fan et al., 2012), which is governed by the rate of $\mathrm{BC}$ aging and the frequency of precipitation (Liu et al., 2011). In this section, we evaluate the extent to which transpacific transport of $\mathrm{BC}$ is tied to the aging process, and employ an idealized $\mathrm{BC}$ transport model (Sect. 2.4) to explain this sensitivity.

\subsection{Sensitivity of the North Pacific $\mathrm{BC}$ to $\mathrm{BC}$ aging}

Figure 5 compares the observed $\mathrm{BC}$ vertical profiles over the North Pacific with those simulated using different e-folding aging times. Although the model biases may partially re-

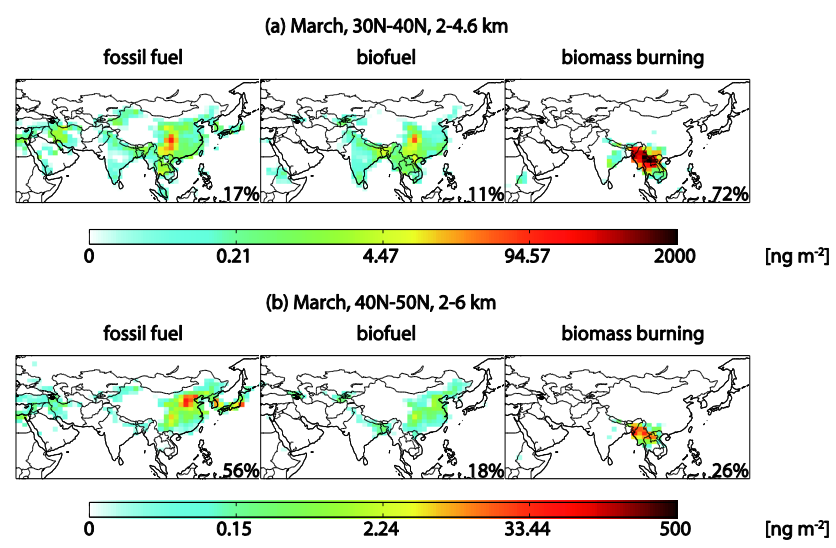

Figure 6. Origin of BC as in Fig. 1, but for (a) $30-40^{\circ} \mathrm{N}, 2-4.6 \mathrm{~km}$ (b) $40-50^{\circ} \mathrm{N}, 2-6 \mathrm{~km}$ over the North Pacific in March, 2010.

sult from the coarse model resolution as well as simplified treatment of emissions (e.g., biomass burnings), the aging process has a significant effect on simulated $\mathrm{BC}$ concentrations. A slower aging process results in higher $\mathrm{BC}$ concentrations, but using a different e-folding time cannot change the vertical pattern of $\mathrm{BC}$ distribution. In most cases when the mid-latitude BC over the North Pacific is dominated by anthropogenic sources (e.g., $40-50^{\circ} \mathrm{N}, 2-6 \mathrm{~km}$, in March, see Fig. 6b), model simulations could be improved when assuming a faster aging process (smaller than $10 \mathrm{~h}$ ). Conversely, when most BC comes from biomass burning in SE (e.g., $30-40^{\circ} \mathrm{N}, 2-4.6 \mathrm{~km}$, see Fig. 6a), a larger e-folding time (larger than $2.5 \mathrm{~d}$ ) may lead to improved agreement between model predicted and observed BC concentrations.

Figure 7 shows the initial values of the cost function $\left(J_{0}\right)$ in inverse modeling with different e-folding aging times. $J_{0}$ can be used to evaluate the model since the penalty error caused by the difference between the prior and posterior emissions is 0 for the first iteration, and a smaller $J_{0}$ means better agreement between model simulations and observations. In March, an e-folding time of about $1 \mathrm{~d}$ minimizes the biases between model predicted and observed BC concentrations, while in April, the model performance is better with a much smaller e-folding time (smaller than $10 \mathrm{~h}$ ), and the model biases do not change much when using an aging rate less than $10 \mathrm{~h}$. As mentioned in Sect. 3, BC over the North Pacific in March mainly originates from biomass burning in $\mathrm{SE}$, while anthropogenic $\mathrm{BC}$ in EA has a major contribution in April. These results suggest that the aging process of anthropogenic $\mathrm{BC}$ may be faster than that of biomass burning $\mathrm{BC}$, possibly because species such as $\mathrm{SO}_{2}$, which are coemitted with $\mathrm{BC}$ from fossil fuel and biofuel combustion in $\mathrm{EA}$, accelerate the aging process of $\mathrm{BC}$. Conversely, a lack of sulfur in biomass burning emissions or little soluble materials coated on freshly emitted $\mathrm{BC}$ may slow down the aging process, reducing the rate of conversion of $\mathrm{BC}$ particles to $\mathrm{CCN}$. 


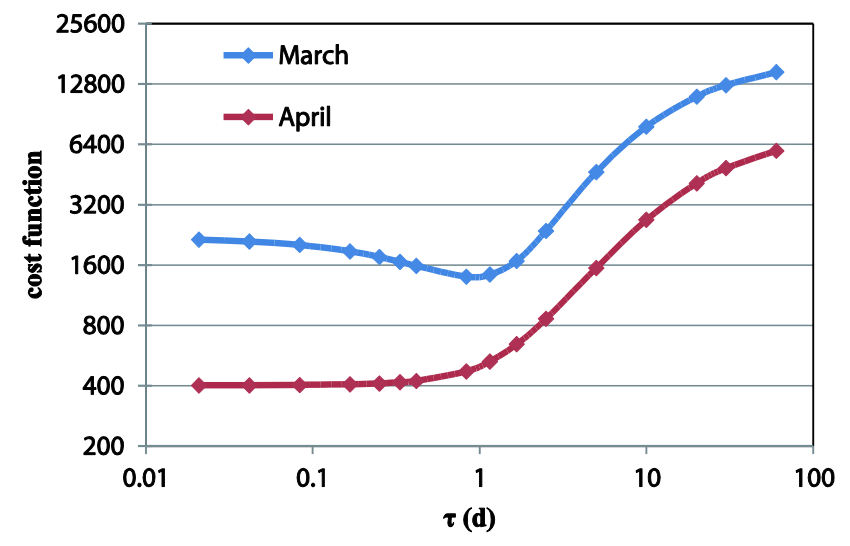

Figure 7. Distribution of the cost functions for the first iteration from sensitivity tests on the aging process.

Chamber studies and measurements have shown that chemical aging of biomass burning aerosols by atmospheric oxidants increases their hygroscopicity and hence their ability to activate as CCN (Akagi et al., 2012; Petters et al., 2009). However, the direct link between the coating thickness and the likelihood of removal of these aerosols has not been determined, and the fate of carbonaceous aerosols is often controlled by the interaction with more hydrophilic species (Petters et al., 2006). The oxidation aging of BC is also affected by ozone and water vapor concentrations, resulting in long BC lifetimes in the tropical areas (Huang et al., 2013). The main pathway for hydrophobic-to-hydrophilic conversion of carbonaceous aerosols is still unclear and further observations (e.g., the hygroscopicity of $\mathrm{BC}$ coating materials) are needed to better understand the mechanism of the aging process.

It should be noted that in our study, neither modifications to the emissions (Fig. 2) nor the fixed aging rate (Fig. 5) are able to significantly improve the GEOS-Chem model simulation of BC over the North Pacific during HIPPO-3, mainly because there are large uncertainties remaining in other factors controlling transpacific transport of $\mathrm{BC}$. We assume a fixed aging time of $\mathrm{BC}$, while some chemical or physical factors may cause the BC aging rate to vary. Huang et al. (2013) implemented a new detailed aging scheme for carbonaceous aerosols in GEOS-Chem to account for both the chemical oxidation and the physical condensation-coagulation effects, resulting in large spatial and temporal variations in the aging time and an improvement in model simulations for the remote areas in the Northern Hemisphere. Wet deposition, which is the main BC sink, is one of the most important factors affecting $\mathrm{BC}$ concentrations in the remote troposphere. Wang et al. (2014) compared GEOS-Chem model simulated $\mathrm{BC}$ with HIPPO observations and found that BC wet scavenging may be much more efficient than what is implemented in models. The treatment of highly uncertain cloud processes in models is important for $\mathrm{BC}$ removal and thus for $\mathrm{BC}$ (a) emission contributions

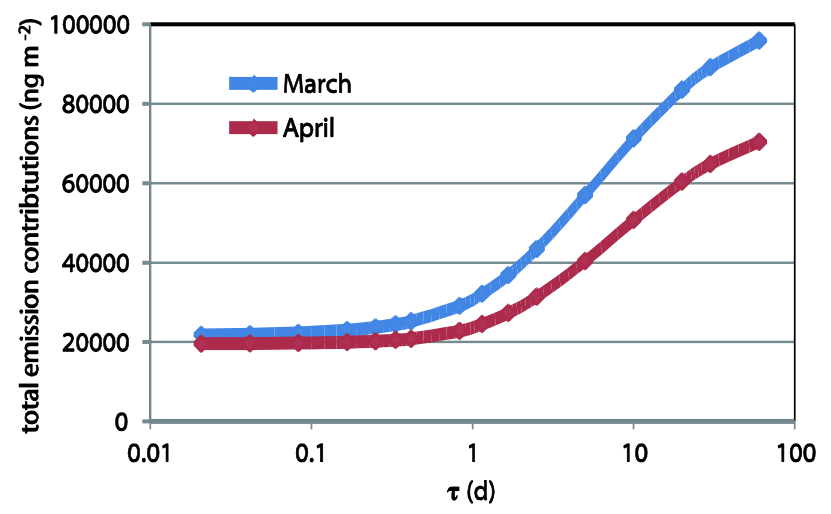

(b) sensitivity of contributions

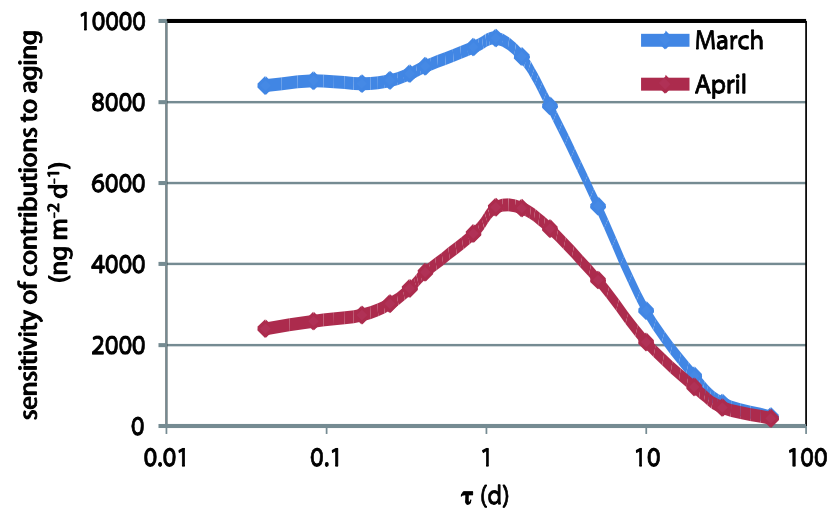

Figure 8. Effect of BC aging on transpacific transport of BC. (a) Total emission contributions to BC over the North Pacific observational domain as a function of $\mathrm{BC}$ aging rate. (b) Sensitivity of total $\mathrm{BC}$ transported to the observational domain from all the sources to the rate of $\mathrm{BC}$ aging (i.e., the rate of change of emissions contributions in (a) with respect to the e-folding aging time $\tau$ ).

simulations, especially at high altitudes. Fan et al. (2012) proposed that the variation of ice formation processes with chemical and physical regimes in the atmosphere is important to $\mathrm{BC}$ removal in models. Here we focus on the fixed aging rate of $\mathrm{BC}$ in model simulations, but the processes mentioned above should be addressed in future work.

\subsection{Precipitation pattern during HIPPO-3}

Along the path of transpacific transport, air masses originating in EA may experience one or more major precipitation events. As shown in Eq. (3), the ratio of the time interval between emissions and precipitation to the e-folding aging time determines the efficiency of wet deposition of $\mathrm{BC}$ during transpacific transport. Given a fixed aging rate in the model, the overall $\mathrm{BC}$ removal efficiency is thereby determined by the timing and removal efficiency of precipitations. In this section, we use a series of model runs with different e-folding aging times to determine the sensitivity of transpacific transport of $\mathrm{BC}$ during HIPPO-3 to the rate of $\mathrm{BC}$ aging. We also 
employ an idealized BC transport model to explore the timing and removal efficiency of major wet removal events during HIPPO-3.

Figure 8a shows total emission contributions from all Asian BC sources to BC over the North Pacific for each sensitivity test on $\mathrm{BC}$ aging. More $\mathrm{BC}$ is transported to the North Pacific when the aging process is slower, while the rate of increase in the BC contributions is not linear (Fig. 8b). In both March and April missions of HIPPO-3, the effect of BC aging on transpacific transport is greater when the e-folding time is small, with the aging process having the largest effect at value of $\tau$ in the range of $1-1.5 \mathrm{~d}$. As $\tau$ is assumed to be $1-2 \mathrm{~d}$ in most models, it is critical to treat BC aging accurately, particularly over the source region, when conducting analysis of long-range transport at mid-latitudes.

The timing of precipitation experienced by the Asian outflow is another factor affecting the transpacific transport. In order to further analyze the characteristics of wet removal of BC during HIPPO-3, we use Eq. (3) to fit the amount of BC transported to the North Pacific $(C)$ in the sensitivity runs as a function of the BC aging timescale $(\tau)$. We assume five major precipitation events during the transpacific transport (i.e., $N=5$ ) and find that the assumption of $N$ does not have a large impact on our conclusions when $N>5$. We also assume $80 \%$ of $\mathrm{BC}$ emitted is hydrophobic (i.e., $\alpha=0.8$ ), which is the same as the assumption in GEOS-Chem. Figure 9 shows the fitting results in March and April missions, where $y$ is the total BC emission contributions and $x$ is the inverse of the e-folding time $(1 / \tau)$. When assuming transpacific transport of $\mathrm{BC}$ is determined by the aging rate, the precipitation time, and the fraction of $\mathrm{BC}$ removed by precipitation, our idealized BC transport model has satisfied fitting precision $\left(R^{2}=0.999\right)$ in both missions and can show some implications for general precipitation and wet removal patterns during HIPPO-3. We derive the timing of each precipitation $\left(T_{n}\right)$ and the associated fractional BC removal $\left(R_{n}\right)$ in Eq. (3) based on the parameters (i.e., $\left.t_{n}, A_{n}, y_{0}\right)$ resolved in the fitting equation (see Fig. 9):

$t_{n}=\frac{1}{T_{n}}, n=1,2, \cdots, N$

$A_{n}=\alpha E R_{n}\left(1-R_{N}\right) \cdots\left(1-R_{n+1}\right), n=1,2, \cdots, N-1$

$A_{N}=\alpha E R_{N}$

$y_{0}=E\left(1-R_{N}\right) \cdots\left(1-R_{1}\right)$

Table 1 shows the estimated time between BC emissions and removal by the $n$th precipitation during HIPPO-3 $\left(T_{1-N}\right)$ and the corresponding $\mathrm{BC}$ removal efficiency $\left(R_{1-N}\right)$, as mentioned in Sect. 2.4. Three out of the five precipitation events are estimated to occur shortly after BC aerosols are emitted (0-3 d) with high wet removal efficiency. For tracers of 1 and 2 week lifetimes, the average transpacific transport time from EA to the western North America in spring is 2-3 weeks (Liu and Mauzerall, 2005), and our results reflect rapid scavenging near BC source regions. Thus, transpacific transport of
Table 1. Parameters derived from the fit of $\mathrm{BC}$ contributions in the sensitivity runs in March and April emissions based on Eq. (3).

\begin{tabular}{lrrrrr}
\hline Parameter & $T_{1}(\mathrm{~d})$ & $T_{2}(\mathrm{~d})$ & $T_{3}(\mathrm{~d})$ & $T_{4}(\mathrm{~d})$ & $T_{5}(\mathrm{~d})$ \\
\hline March & 0.09 & 0.52 & 2.0 & 5.5 & 17.5 \\
April & 0.13 & 0.79 & 2.5 & 7.0 & 19.3 \\
Parameter & $R_{1}$ & $R_{2}$ & $R_{3}$ & $R_{4}$ & $R_{5}$ \\
March & $9.1 \%$ & $25.7 \%$ & $49.2 \%$ & $38.2 \%$ & $18.0 \%$ \\
April & $4.5 \%$ & $20.6 \%$ & $46.6 \%$ & $34.8 \%$ & $19.0 \%$ \\
\hline
\end{tabular}

BC during the HIPPO-3 period is highly sensitive to BC aging when the aging rate is fast. This indicates the importance of the aging rate of $\mathrm{BC}$ close to the source region, implying a need to simulate the aging at a process level in order to better constrain the global abundance and climate forcing of BC.

\section{Conclusions}

The adjoint of the GEOS-Chem model is applied to analyze the source of $\mathrm{BC}$ reaching the atmospheric column above the North Pacific during HIPPO-3. Although most BC over the North Pacific during spring originates in Asia, the sources of BC in March and April missions are quite different. Biomass burning in SE, which peaks in March, is a major source of BC transported to the North Pacific during March. In April, fast transpacific transport of air pollution brings anthropogenic $\mathrm{BC}$ emitted from fossil fuel and biofuel combustion in EA to the North Pacific.

Simulations using GEOS-Chem model generally resolve the spatial and temporal variation of $\mathrm{BC}$ concentrations over the North Pacific, but are unable to reproduce the low end and high end of BC observations. The model tends to over- or underestimate $\mathrm{BC}$ concentrations at various locations within the HIPPO-3 observational domain over the North Pacific, with no consistent bias. The discrepancy is caused by many factors, including the uncertainty in $\mathrm{BC}$ emissions and the model's inability to accurately represent BC transport processes. The optimization of BC emissions using HIPPO data generally yields an increase in Asian anthropogenic BC emissions and relocation of SE biomass burning BC (i.e., decrease across Burma and increase over North Laos) in March measurements, and it results in a decrease in $\mathrm{BC}$ emissions from all sources in April measurements, with the extent of change varying by location. Since the large uncertainties in BC transport processes limit the capability of inverse modeling in optimization of $\mathrm{BC}$ emissions, we provide only an approximate estimate of Asian BC emissions. Similar analysis using a finer model resolution may improve the results and could be the subject of future studies.

Chemical aging of $\mathrm{BC}$ aerosols is found to be one of the most important processes controlling transpacific transport of BC. As inferred from the source analysis and the sensitivity simulations, BC from biomass burning may 
(a) March

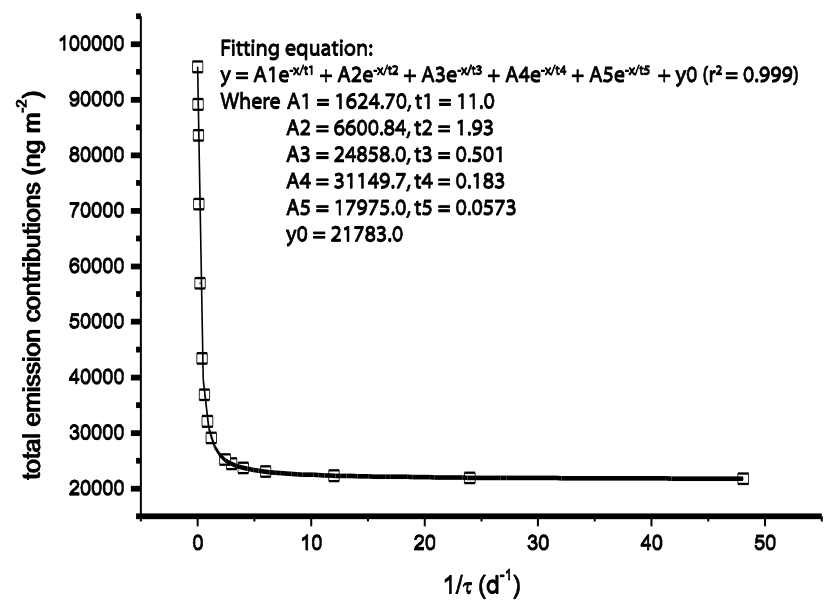

(b) April

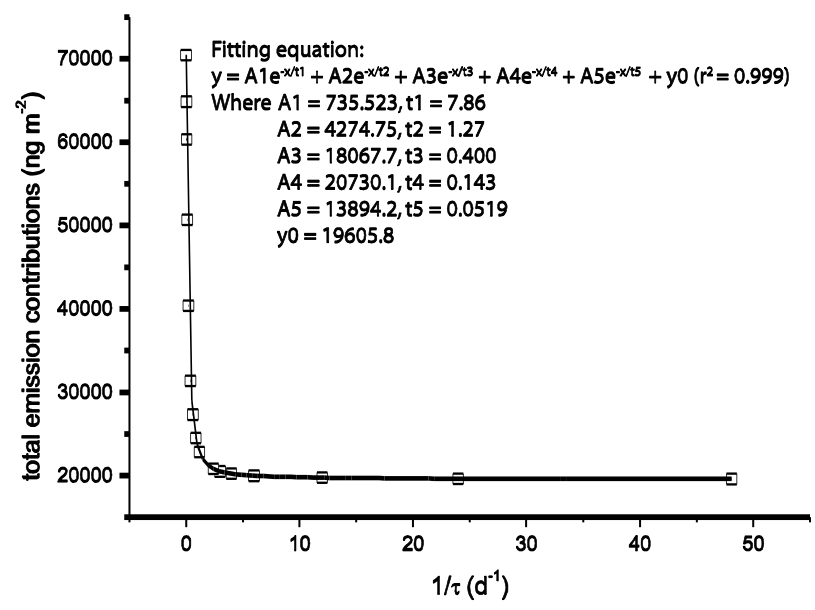

Figure 9. Result of fitting transpacific transport of BC with different e-folding aging times to the idealized transport model (Sect. 2.4) in (a) March 2010 and (b) April 2010. Points indicate results from full CTM simulations. Lines show fit from Eq. (3).

experience a slower aging process than anthropogenic BC from fossil fuel and biofuel sources when monthly biomass burning emissions are applied. In addition, using an idealized $\mathrm{BC}$ transport model, we find that the mid-latitude air masses sampled during HIPPO-3 may have experienced a series of precipitation events, particularly near the EA and SE source region. Consequently, $\mathrm{BC}$ transport is highly sensitive to the aging rate when the aging process is fast. The effect of $\mathrm{BC}$ aging peaks when the e-folding time is about $1-1.5 \mathrm{~d}$, which is within the range assumed in many models. As other processes in BC transport also have large uncertainties, future studies should evaluate the effect of these processes, especially wet deposition near the source region, on the longrange transport of $\mathrm{BC}$.
Acknowledgements. We thank two anonymous reviewers for their thoughtful comments and helpful suggestions. We thank R. Gao for helpful discussion on HIPPO measurements. We also thank B. Yokelson, S. Nakao, A. Perring and M. Petters for helpful suggestions on BC aging. This work was supported by funding from the National Natural Science Foundation of China under awards 41222011, 41390240 and 41130754, the Research Project of Chinese Ministry of Education no. 113001A, the "863" Hi-Tech R\&D Program of China under grant no. 2012AA063303, as well as the 111 Project (B14001). D. K. Henze acknowledges support from EPA STAR grant 83503701, and this work does not reflect official EPA views or policies. J.-T. Lin is partly supported by the National Natural Science Foundation of China, grant 41175127.

Edited by: Y. Balkanski

\section{References}

Akagi, S. K., Craven, J. S., Taylor, J. W., McMeeking, G. R., Yokelson, R. J., Burling, I. R., Urbanski, S. P., Wold, C. E., Seinfeld, J. H., Coe, H., Alvarado, M. J., and Weise, D. R.: Evolution of trace gases and particles emitted by a chaparral fire in California, Atmos. Chem. Phys., 12, 1397-1421, doi:10.5194/acp-12-13972012, 2012.

Bey, I., Jacob, D. J., Yantosca, R. M., Logan, J. A., Field, B. D., Fiore, A. M., Li, Q. B., Liu, H. G. Y., Mickley, L. J., and Schultz, M. G.: Global modeling of tropospheric chemistry with assimilated meteorology: Model description and evaluation, J. Geophys. Res.-Atmos., 106, 23073-23095, doi:10.1029/2001jd000807, 2001.

Bond, T. C., Streets, D. G., Yarber, K. F., Nelson, S. M., Woo, J. H., and Klimont, Z.: A technology-based global inventory of black and organic carbon emissions from combustion, J. Geophys. Res.-Atmos., 109, D14203, doi:10.1029/2003jd003697, 2004.

Bond, T. C., Bhardwaj, E., Dong, R., Jogani, R., Jung, S. K., Roden, C., Streets, D. G., and Trautmann, N. M.: Historical emissions of black and organic carbon aerosol from energy-related combustion, 1850-2000, Global Biogeochem. Cy., 21, Gb2018, doi:10.1029/2006gb002840, 2007.

Bond, T. C., Doherty, S., Fahey, D., Forster, P., Berntsen, T., DeAngelo, B., Flanner, M., Ghan, S., Kärcher, B., and Koch, D.: Bounding the role of black carbon in the climate system: A scientific assessment, J. Geophys. Res.-Atmos., 118, 5380-5552, doi:10.1002/jgrd.50171, 2013.

Byrd, R. H., Lu, P. H., Nocedal, J., and Zhu, C. Y.: A Limited Memory Algorithm for Bound Constrained Optimization, Siam J. Sci. Comput., 16, 1190-1208, doi:10.1137/0916069, 1995.

Chung, S. H. and Seinfeld, J. H.: Global distribution and climate forcing of carbonaceous aerosols, J. Geophys. Res.-Atmos., 107, 4407, doi:10.1029/2001jd001397, 2002.

Cooke, W. F., Ramaswamy, V., and Kasibhatla, P.: A general circulation model study of the global carbonaceous aerosol distribution, J. Geophys. Res.-Atmos., 107, 4279, doi:10.1029/2001jd001274, 2002.

Cozic, J., Verheggen, B., Mertes, S., Connolly, P., Bower, K., Petzold, A., Baltensperger, U., and Weingartner, E.: Scavenging of black carbon in mixed phase clouds at the high alpine site Jungfraujoch, Atmos. Chem. Phys., 7, 1797-1807, doi:10.5194/acp-7-1797-2007, 2007. 
Croft, B., Lohmann, U., and von Salzen, K.: Black carbon ageing in the Canadian Centre for Climate modelling and analysis atmospheric general circulation model, Atmos. Chem. Phys., 5, 19311949, doi:10.5194/acp-5-1931-2005, 2005.

Duncan, B. N., Martin, R. V., Staudt, A. C., Yevich, R., and Logan, J. A.: Interannual and seasonal variability of biomass burning emissions constrained by satellite observations, J. Geophys. Res.-Atmos., 108, 4100, doi:10.1029/2002jd002378, 2003.

Fan, S. M., Schwarz, J. P., Liu, J., Fahey, D. W., Ginoux, P., Horowitz, L. W., Levy, H., Ming, Y., and Spackman, J. R.: Inferring ice formation processes from global-scale black carbon profiles observed in the remote atmosphere and model simulations, J. Geophys. Res.-Atmos., 117, D23205, doi:10.1029/2012jd018126, 2012.

Fiore, A. M., Jacob, D. J., Bey, I., Yantosca, R. M., Field, B. D., Fusco, A. C., and Wilkinson, J. G.: Background ozone over the United States in summer: Origin, trend, and contribution to pollution episodes, J. Geophys. Res.-Atmos., 107, 4275, doi:10.1029/2001jd000982, 2002.

Fiore, A. M., Naik, V., Spracklen, D. V., Steiner, A., Unger, N., Prather, M., Bergmann, D., Cameron-Smith, P. J., Cionni, I., Collins, W. J., Dalsoren, S., Eyring, V., Folberth, G. A., Ginoux, P., Horowitz, L. W., Josse, B., Lamarque, J. F., MacKenzie, I. A., Nagashima, T., O’Connor, F. M., Righi, M., Rumbold, S. T., Shindell, D. T., Skeie, R. B., Sudo, K., Szopa, S., Takemura, T., and Zeng, G.: Global air quality and climate, Chem. Soc. Rev., 41, 6663-6683, doi:10.1039/C2cs35095e, 2012.

Fu, T.-M., Cao, J. J., Zhang, X. Y., Lee, S. C., Zhang, Q., Han, Y. M., Qu, W. J., Han, Z., Zhang, R., Wang, Y. X., Chen, D., and Henze, D. K.: Carbonaceous aerosols in China: top-down constraints on primary sources and estimation of secondary contribution, Atmos. Chem. Phys., 12, 2725-2746, doi:10.5194/acp12-2725-2012, 2012.

Gao, R. S., Schwarz, J. P., Kelly, K. K., Fahey, D. W., Watts, L. A., Thompson, T. L., Spackman, J. R., Slowik, J. G., Cross, E. S., Han, J. H., Davidovits, P., Onasch, T. B., and Worsnop, D. R.: A novel method for estimating lightscattering properties of soot aerosols using a modified singleparticle soot photometer, Aerosol Sci. Tech., 41, 125-135, doi:10.1080/02786820601118398, 2007.

Hakami, A., Henze, D. K., Seinfeld, J. H., Chai, T., Tang, Y., Carmichael, G. R., and Sandu, A.: Adjoint inverse modeling of black carbon during the Asian Pacific Regional Aerosol Characterization Experiment, J. Geophys. Res.-Atmos., 110, D14301, doi:10.1029/2004jd005671, 2005.

Heald, C. L., Jacob, D. J., Jones, D. B. A., Palmer, P. I., Logan, J. A., Streets, D. G., Sachse, G. W., Gille, J. C., Hoffman, R. N., and Nehrkorn, T.: Comparative inverse analysis of satellite (MOPITT) and aircraft (TRACE-P) observations to estimate Asian sources of carbon monoxide, J. Geophys. Res.-Atmos., 109, D23306, doi:10.1029/2004jd005185, 2004.

Henze, D. K., Hakami, A., and Seinfeld, J. H.: Development of the adjoint of GEOS-Chem, Atmos. Chem. Phys., 7, 2413-2433, doi:10.5194/acp-7-2413-2007, 2007.

Henze, D. K., Seinfeld, J. H., and Shindell, D. T.: Inverse modeling and mapping US air quality influences of inorganic $\mathrm{PM}_{2.5}$ precursor emissions using the adjoint of GEOS-Chem, Atmos. Chem. Phys., 9, 5877-5903, doi:10.5194/acp-9-5877-2009, 2009.
Highwood, E. J. and Kinnersley, R. P.: When smoke gets in our eyes: The multiple impacts of atmospheric black carbon on climate, air quality and health, Environ. Int., 32, 560-566, doi:10.1016/j.envint.2005.12.003, 2006.

Holzer, M., Hall, T. M., and Stull, R. B.: Seasonality and weatherdriven variability of transpacific transport, J. Geophys. Res.Atmos., 110, D23103, doi:10.1029/2005jd006261, 2005.

Huang, Y., Wu, S., Dubey, M. K., and French, N. H. F.: Impact of aging mechanism on model simulated carbonaceous aerosols, Atmos. Chem. Phys., 13, 6329-6343, doi:10.5194/acp-13-63292013, 2013.

Jaegle, L., Jacob, D. J., Brune, W. H., Tan, D., Faloona, I. C., Weinheimer, A. J., Ridley, B. A., Campos, T. L., and Sachse, G. W.: Sources of $\mathrm{HO}_{\mathrm{x}}$ and production of ozone in the upper troposphere over the United States, Geophys. Res. Lett., 25, 17091712, doi:10.1029/98g100041, 1998.

Kharol, S. K., Martin, R. V., Philip, S., Vogel, S., Henze, D. K., Chen, D., Wang, Y., Zhang, Q., and Heald, C. L.: Persistent sensitivity of Asian aerosol to emissions of nitrogen oxides, Geophys. Res. Lett., 40, 1021-1026, doi:10.1002/Grl.50234, 2013.

Koch, D.: Transport and direct radiative forcing of carbonaceous and sulfate aerosols in the GISS GCM, J. Geophys. Res.-Atmos., 106, 20311-20332, doi:10.1029/2001jd900038, 2001.

Koch, D. and Hansen, J.: Distant origins of Arctic black carbon: A Goddard Institute for Space Studies ModelE experiment, J. Geophys. Res.-Atmos., 110, D04204, doi:10.1029/2004jd005296, 2005.

Koch, D., Schulz, M., Kinne, S., McNaughton, C., Spackman, J. R., Balkanski, Y., Bauer, S., Berntsen, T., Bond, T. C., Boucher, O., Chin, M., Clarke, A., De Luca, N., Dentener, F., Diehl, T., Dubovik, O., Easter, R., Fahey, D. W., Feichter, J., Fillmore, D., Freitag, S., Ghan, S., Ginoux, P., Gong, S., Horowitz, L., Iversen, T., Kirkevåg, A., Klimont, Z., Kondo, Y., Krol, M., Liu, X., Miller, R., Montanaro, V., Moteki, N., Myhre, G., Penner, J. E., Perlwitz, J., Pitari, G., Reddy, S., Sahu, L., Sakamoto, H., Schuster, G., Schwarz, J. P., Seland, Ø., Stier, P., Takegawa, N., Takemura, T., Textor, C., van Aardenne, J. A., and Zhao, Y.: Evaluation of black carbon estimations in global aerosol models, Atmos. Chem. Phys., 9, 9001-9026, doi:10.5194/acp-9-9001-2009, 2009.

Koffi, B., Schulz, M., Breon, F. M., Griesfeller, J., Winker, D., Balkanski, Y., Bauer, S., Berntsen, T., Chin, M. A., Collins, W. D., Dentener, F., Diehl, T., Easter, R., Ghan, S., Ginoux, P., Gong, S. L., Horowitz, L. W., Iversen, T., Kirkevag, A., Koch, D., Krol, M., Myhre, G., Stier, P., and Takemura, T.: Application of the CALIOP layer product to evaluate the vertical distribution of aerosols estimated by global models: AeroCom phase I results, J. Geophys. Res.-Atmos., 117, D10201, doi:10.1029/2011jd016858, 2012.

Kopacz, M., Jacob, D. J., Henze, D. K., Heald, C. L., Streets, D. G., and Zhang, Q.: Comparison of adjoint and analytical Bayesian inversion methods for constraining Asian sources of carbon monoxide using satellite (MOPITT) measurements of CO columns, J. Geophys. Res.-Atmos., 114, D04305, doi:10.1029/2007jd009264, 2009.

Kopacz, M., Mauzerall, D. L., Wang, J., Leibensperger, E. M., Henze, D. K., and Singh, K.: Origin and radiative forcing of black carbon transported to the Himalayas and Tibetan Plateau, 
Atmos. Chem. Phys., 11, 2837-2852, doi:10.5194/acp-11-28372011, 2011.

Laborde, M., Schnaiter, M., Linke, C., Saathoff, H., Naumann, K.H., Möhler, O., Berlenz, S., Wagner, U., Taylor, J. W., Liu, D., Flynn, M., Allan, J. D., Coe, H., Heimerl, K., Dahlkötter, F., Weinzierl, B., Wollny, A. G., Zanatta, M., Cozic, J., Laj, P., Hitzenberger, R., Schwarz, J. P., and Gysel, M.: Single Particle Soot Photometer intercomparison at the AIDA chamber, Atmos. Meas. Tech., 5, 3077-3097, doi:10.5194/amt-5-3077-2012, 2012.

Lamarque, J.-F., Bond, T. C., Eyring, V., Granier, C., Heil, A., Klimont, Z., Lee, D., Liousse, C., Mieville, A., Owen, B., Schultz, M. G., Shindell, D., Smith, S. J., Stehfest, E., Van Aardenne, J., Cooper, O. R., Kainuma, M., Mahowald, N., McConnell, J. R., Naik, V., Riahi, K., and van Vuuren, D. P.: Historical (1850-2000) gridded anthropogenic and biomass burning emissions of reactive gases and aerosols: methodology and application, Atmos. Chem. Phys., 10, 7017-7039, doi:10.5194/acp10-7017-2010, 2010.

Lin , J. T. and McElroy, M. B.: Impacts of boundary layer mixing on pollutant vertical profiles in the lower troposphere: Implications to satellite remote sensing, Atmos. Environ., 44, 17261739, doi:10.1016/j.atmosenv.2010.02.009, 2010.

Lin, J. T., Wuebbles, D. J., and Liang, X. Z.: Effects of intercontinental transport on surface ozone over the United States: Present and future assessment with a global model, Geophys. Res. Lett., 35, L02805, doi:10.1029/2007g1031415, 2008.

Lin, J.-T., Liu, Z., Zhang, Q., Liu, H., Mao, J., and Zhuang, G.: Modeling uncertainties for tropospheric nitrogen dioxide columns affecting satellite-based inverse modeling of nitrogen oxides emissions, Atmos. Chem. Phys., 12, 12255-12275, doi:10.5194/acp-12-12255-2012, 2012.

Lin, J. T., Pan, D., Davis, S. J., Zhang, Q., He, K. B., Wang, C., Streets, D. G., Wuebbles, D. J., and Guan, D. B.: China's international trade and air pollution in the United States, P. Natl. Acad. Sci. USA, 111, 1736-1741, doi:10.1073/pnas.1312860111, 2014.

Lin, M. Y., Fiore, A. M., Horowitz, L. W., Cooper, O. R., Naik, V., Holloway, J., Johnson, B. J., Middlebrook, A. M., Oltmans, S. J., Pollack, I. B., Ryerson, T. B., Warner, J. X., Wiedinmyer, C., Wilson, J., and Wyman, B.: Transport of Asian ozone pollution into surface air over the western United States in spring, J. Geophys. Res.-Atmos., 117, D00v07, doi:10.1029/2011jd016961, 2012.

Liu, J. F. and Mauzerall, D. L.: Estimating the average time for intercontinental transport of air pollutants, Geophys. Res. Lett., 32, L11814, doi:10.1029/2005g1022619, 2005.

Liu, J. F., Mauzerall, D. L., and Horowitz, L. W.: Analysis of seasonal and interannual variability in transpacific transport, J. Geophys. Res.-Atmos., 110, D04302, doi:10.1029/2004jd005207, 2005.

Liu, J. F., Mauzerall, D. L., and Horowitz, L. W.: Evaluating inter-continental transport of fine aerosols: (2) Global health impact, Atmos Environ, 43, 4339-4347, doi:10.1016/j.atmosenv.2009.05.032, 2009a.

Liu, J. F., Mauzerall, D. L., Horowitz, L. W., Ginoux, P., and Fiore, A. M.: Evaluating inter-continental transport of fine aerosols: (1) Methodology, global aerosol distribution and optical depth, Atmos. Environ., 43, 4327-4338, doi:10.1016/j.atmosenv.2009.03.054, 2009b.
Liu, J. F., Fan, S. M., Horowitz, L. W., and Levy, H.: Evaluation of factors controlling long-range transport of black carbon to the Arctic, J. Geophys. Res.-Atmos., 116, D04307, doi:10.1029/2010jd015145, 2011.

Lu, Z., Zhang, Q., and Streets, D. G.: Sulfur dioxide and primary carbonaceous aerosol emissions in China and India, 1996-2010, Atmos. Chem. Phys., 11, 9839-9864, doi:10.5194/acp-11-98392011, 2011.

Müller, J.-F. and Stavrakou, T.: Inversion of $\mathrm{CO}$ and $\mathrm{NO}_{\mathrm{x}}$ emissions using the adjoint of the IMAGES model, Atmos. Chem. Phys., 5, 1157-1186, doi:10.5194/acp-5-1157-2005, 2005.

Oshima, N., Koike, M., Kondo, Y., Nakamura, H., Moteki, N., Matsui, H., Takegawa, N., and Kita, K.: Vertical transport mechanisms of black carbon over East Asia in spring during the A-FORCE aircraft campaign, J. Geophys. Res.-Atmos., 118, 13175-13198, doi:10.1002/2013jd020262, 2013.

Park, R. J., Jacob, D. J., Chin, M., and Martin, R. V.: Sources of carbonaceous aerosols over the United States and implications for natural visibility, J. Geophys. Res.-Atmos., 108, 4355, doi:10.1029/2002jd003190, 2003.

Park, R. J., Jacob, D. J., Palmer, P. I., Clarke, A. D., Weber, R. J., Zondlo, M. A., Eisele, F. L., Bandy, A. R., Thornton, D. C., Sachse, G. W., and Bond, T. C.: Export efficiency of black carbon aerosol in continental outflow: Global implications, J. Geophys. Res.-Atmos., 110, D11205, doi:10.1029/2004jd005432, 2005.

Petters, M. D., Prenni, A. J., Kreidenweis, S. M., DeMott, P. J., Matsunaga, A., Lim, Y. B., and Ziemann, P. J.: Chemical aging and the hydrophobic-to-hydrophilic conversion of carbonaceous aerosol, Geophys. Res. Lett., 33, L24806, doi:10.1029/2006gl027249, 2006.

Petters, M. D., Carrico, C. M., Kreidenweis, S. M., Prenni, A. J., DeMott, P. J., Collett, J. L., and Moosmuller, H.: Cloud condensation nucleation activity of biomass burning aerosol, J. Geophys. Res.-Atmos., 114, D22205, doi:10.1029/2009jd012353, 2009.

Ramanathan, V. and Carmichael, G.: Global and regional climate changes due to black carbon, Nat. Geosci., 1, 221-227, doi:10.1038/Ngeo156, 2008.

Rastigejev, Y., Park, R., Brenner, M. P., and Jacob, D. J.: Resolving intercontinental pollution plumes in global models of atmospheric transport, J. Geophys. Res.-Atmos., 115, D02302, doi:10.1029/2009jd012568, 2010.

Riemer, N., Vogel, H., and Vogel, B.: Soot aging time scales in polluted regions during day and night, Atmos. Chem. Phys., 4, 1885-1893, doi:10.5194/acp-4-1885-2004, 2004.

Riemer, N., West, M., Zaveri, R., and Easter, R.: Estimating black carbon aging time-scales with a particle-resolved aerosol model, J. Aerosol Sci., 41, 143-158, doi:10.1016/j.jaerosci.2009.08.009, 2010.

Rodgers, C. D.: Inverse methods for atmospheric sounding: theory and practice, World scientific Singapore, 2000.

Schwarz, J. P., Gao, R. S., Spackman, J. R., Watts, L. A., Thomson, D. S., Fahey, D. W., Ryerson, T. B., Peischl, J., Holloway, J. S., Trainer, M., Frost, G. J., Baynard, T., Lack, D. A., de Gouw, J. A., Warneke, C., and Del Negro, L. A.: Measurement of the mixing state, mass, and optical size of individual black carbon particles in urban and biomass burning emissions, Geophys. Res. Lett., 35, L13810, doi:10.1029/2008g1033968, 2008. 
Schwarz, J. P., Spackman, J. R., Gao, R. S., Watts, L. A., Stier, P., Schulz, M., Davis, S. M., Wofsy, S. C., and Fahey, D. W.: Globalscale black carbon profiles observed in the remote atmosphere and compared to models (vol 37, art L18812, 2010), Geophys. Res. Lett., 37, L23804, doi:10.1029/2010g1046007, 2010.

Schwarz, J. P., Samset, B. H., Perring, A. E., Spackman, J. R., Gao, R. S., Stier, P., Schulz, M., Moore, F. L., Ray, E. A., and Fahey, D. W.: Global-scale seasonally resolved black carbon vertical profiles over the Pacific, Geophys. Res. Lett., 40, 5542-5547, doi:10.1002/2013g1057775, 2013.

Shindell, D. T., Chin, M., Dentener, F., Doherty, R. M., Faluvegi, G., Fiore, A. M., Hess, P., Koch, D. M., MacKenzie, I. A., Sanderson, M. G., Schultz, M. G., Schulz, M., Stevenson, D. S., Teich, H., Textor, C., Wild, O., Bergmann, D. J., Bey, I., Bian, H., Cuvelier, C., Duncan, B. N., Folberth, G., Horowitz, L. W., Jonson, J., Kaminski, J. W., Marmer, E., Park, R., Pringle, K. J., Schroeder, S., Szopa, S., Takemura, T., Zeng, G., Keating, T. J., and Zuber, A.: A multi-model assessment of pollution transport to the Arctic, Atmos. Chem. Phys., 8, 5353-5372, doi:10.5194/acp-85353-2008, 2008.

Textor, C., Schulz, M., Guibert, S., Kinne, S., Balkanski, Y., Bauer, S., Berntsen, T., Berglen, T., Boucher, O., Chin, M., Dentener, F., Diehl, T., Feichter, J., Fillmore, D., Ginoux, P., Gong, S., Grini, A., Hendricks, J., Horowitz, L., Huang, P., Isaksen, I. S. A., Iversen, T., Kloster, S., Koch, D., Kirkevåg, A., Kristjansson, J. E., Krol, M., Lauer, A., Lamarque, J. F., Liu, X., Montanaro, V., Myhre, G., Penner, J. E., Pitari, G., Reddy, M. S., Seland, Ø., Stier, P., Takemura, T., and Tie, X.: The effect of harmonized emissions on aerosol properties in global models an AeroCom experiment, Atmos. Chem. Phys., 7, 4489-4501, doi:10.5194/acp-7-4489-2007, 2007.

van der Werf, G. R., Randerson, J. T., Giglio, L., Collatz, G. J., Mu, M., Kasibhatla, P. S., Morton, D. C., DeFries, R. S., Jin, Y., and van Leeuwen, T. T.: Global fire emissions and the contribution of deforestation, savanna, forest, agricultural, and peat fires (19972009), Atmos. Chem. Phys., 10, 11707-11735, doi:10.5194/acp10-11707-2010, 2010.

Wang, Q., Jacob, D. J., Fisher, J. A., Mao, J., Leibensperger, E. M., Carouge, C. C., Le Sager, P., Kondo, Y., Jimenez, J. L., Cubison, M. J., and Doherty, S. J.: Sources of carbonaceous aerosols and deposited black carbon in the Arctic in winter-spring: implications for radiative forcing, Atmos. Chem. Phys., 11, 1245312473, doi:10.5194/acp-11-12453-2011, 2011.

Wang, Q., Jacob, D. J., Spackman, J. R., Perring, A. E., Schwarz, J. P., Moteki, N., Marais, E. A., Ge, C., Wang, J., and Barrett, S. R. H.: Global budget and radiative forcing of black carbon aerosol: Constraints from pole-to-pole (HIPPO) observations across the Pacific, J. Geophys. Res.-Atmos., 119, 195-206, doi:10.1002/2013jd020824, 2014.
Wang, X., Wang, Y., Hao, J., Kondo, Y., Irwin, M., Munger, J. W., and Zhao, Y.: Top-down estimate of China's black carbon emissions using surface observations: Sensitivity to observation representativeness and transport model error, J. Geophys. Res.Atmos., 118, 5781-5795, doi:10.1002/jgrd.50397, 2013.

Wang, Y. H., Jacob, D. J., and Logan, J. A.: Global simulation of tropospheric O-3-NO $\mathrm{N}_{\mathrm{x}}$-hydrocarbon chemistry 3. Origin of tropospheric ozone and effects of nonmethane hydrocarbons, J. Geophys. Res.-Atmos., 103, 10757-10767, doi:10.1029/98jd00156, 1998.

Wofsy, S. C., Team, H. S., Team, C. M., and Team, S.: HIAPER Pole-to-Pole Observations (HIPPO): fine-grained, globalscale measurements of climatically important atmospheric gases and aerosols, Philos. T. R. Soc. A, 369, 2073-2086, doi:10.1098/rsta.2010.0313, 2011.

Wofsy, S. C., Daube, B. C., Jimenez, R., Kort, E., Pittman, J. V., Park, S., Commane, R., Xiang, B., Santoni, G., Jacob, D., Fisher, J., Pickett-Heaps, C., Wang, H., Wecht, K., Wang, Q.-Q., Stephens, B. B., Shertz, S., Watt, A. S., Romashkin, P., Campos, T., Haggerty, J., Cooper, W. A., Rogers, D., Beaton, S., Hendershot, R., Elkins, J. W., Fahey, D. W., Gao, R. S., Moore, F., Montzka, S. A., Schwarz, J. P., Perring, A. E., Hurst, D., Miller, B. R., Sweeney, C., Oltmans, S., Nance, D., Hintsa, E., Dutton, G., Watts, L. A., Spackman, J. R., Rosenlof, K. H., Ray, E. A., Hall, B., Zondlo, M. A., Diao, M., Keeling, R., Bent, J., Atlas, E. L., Lueb, R., and Mahoney, M. J.: HIPPO Merged 10-second Meteorology, Atmospheric Chemistry, Aerosol Data (R_20121129), Carbon Dioxide Information Analysis Center, Oak Ridge National Laboratory, Oak Ridge, Tennessee, USA, doi:10.3334/CDIAC/hippo_010 (Release 20121129), 2012.

Wuebbles, D. J., Lei, H., and Lin, J. T.: Intercontinental transport of aerosols and photochemical oxidants from Asia and its consequences, Environ. Pollut., 150, 65-84, doi:10.1016/j.envpol.2007.06.066, 2007.

Zhang, L., Jacob, D. J., Kopacz, M., Henze, D. K., Singh, K., and Jaffe, D. A.: Intercontinental source attribution of ozone pollution at western US sites using an adjoint method, Geophys. Res. Lett., 36, L11810, doi:10.1029/2009g1037950, 2009.

Zhang, M. G., Han, Z. W., and Zhu, L. Y.: Simulation of atmospheric aerosols in East Asia using modeling system RAMS-CMAQ: Model evaluation, China Part, 5, 321-327, doi:10.1016/j.cpart.2007.07.002, 2007.

Zhu, C., Byrd, R. H., Lu, P., and Nocedal, J.: L-BFGS-B: a limited memory FORTRAN code for solving bound constrained optimization problems, Dept. of Electrical Engineering and Computer Science, Northwestern Univ., TR NAM-11, Evanston, IL, 1994.

Zuberi, B., Johnson, K. S., Aleks, G. K., Molina, L. T., and Laskin, A.: Hydrophilic properties of aged soot, Geophys. Res. Lett., 32, L01807, doi:10.1029/2004g1021496, 2005. 